\title{
Chemical profile of manually extracted andiroba oil (Carapa guianensis Aubl., Meliaceae) from Mamangal community, located in Igarapé-Miri, Pará, Brazil
}

Perfil químico do óleo de andiroba (Carapa guianensis Aubl., Meliaceae) extraído manualmente na comunidade Mamangal, localizada em Igarapé-Miri, Pará, Brasil

\author{
R. L. de Sousa*1; S. G. Silva ${ }^{2}$ J. M. Costa 3 ; W. A. da Costa ${ }^{4}$; A. A. B. Maia ${ }^{1}$; M. \\ S. de Oliveira ${ }^{5}$; E. H. A. Andrade ${ }^{5}$ \\ ${ }^{1}$ Universidade Federal do Pará "Campus Universitário de Abaetetuba” (UFPA), 684400-00, Abaetetuba-PA, Brasil. \\ ${ }^{2}$ Secretaria do Estado de Educação (SEDUC), 66820-000, Belém-PA, Brasil \\ ${ }^{3}$ Instituto Federal do Pará "Campus de Abaetetuba (IFPA), 684400-00, Abaetetuba-PA, Brasil \\ ${ }^{4}$ Programa de Pós-Graduação em Engenharia de Recursos Naturais (UFPA), 66075-900, Belém-PA, Brasil \\ ${ }^{5}$ Laboratório Adolpho Ducke, Coordenação de Botânica, Museu Paraense Emílio Goeldi, 66077-830, Belém-PA, \\ Brasil
}

*ronaldosousa@ufpa.br

(Recebido em 13 de novembro de 2020, aceito em 28 de dezembro de 2021)

Carapa guianensis species belongs to the Meliaceae family and, in the Brazilian Amazon, it has great importance in folk medicine, mainly because the oil extracted from its seeds presents varied biological activities. Thus, the present work aimed to analyze, by gas phase chromatography coupled to mass spectrometry (GC/MS), the chemical composition of manually extracted andiroba oil, from Mamangal community, located in Igarapé-Miri, Pará, Brazil. As results, $99.63 \%$ of the constituents of the oil sample were identified and quantified from which the main components were oleic, palmitic, stearic, and linoleic acids. The manual oil extraction from andiroba seeds in the Mamangal community is sustainable and economically viable. Due to the high content of saturated and unsaturated fatty acids $C$. guianensis oil can be considered interesting useful for pharmaceutical and cosmetic industries. Indeed, the unsaturated fatty acids represented $57.5 \%$ of the oil constituents, among which the essential ones stand out, as they have great applicability in healing drugs formulation.

Keywords: andiroba oil, Carapa guianensis, fatty acids.

A espécie Carapa guianensis pertence à família Meliaceae e, na Amazônia brasileira, tem grande importância na medicina popular, principalmente porque o óleo extraído de suas sementes apresenta atividades biológicas variadas. Assim, o presente trabalho teve como objetivo analisar, por cromatografia em fase gasosa acoplada à espectrometria de massas (CG/EM), a composição química do óleo de andiroba extraído manualmente, da comunidade Mamangal, localizada em Igarapé-Miri, Pará, Brasil. Como resultado 99,63\% dos constituintes da amostra de óleo foram identificados e quantificados, dentre os quais os principais componentes foram os ácidos oléico, palmítico, esteárico e linoléico. A extração manual do óleo de sementes de andiroba na comunidade Mamangal é sustentável e economicamente viável. Devido ao alto teor de ácidos graxos saturados e insaturados, o óleo de $C$. guianensis pode ser útil para as indústrias farmacêutica e cosmética. De fato, os ácidos graxos insaturados representaram 57,5\% dos constituintes do óleo, entre os quais se destacam os essenciais, por apresentarem grande aplicabilidade na formulação de medicamentos curativos.

Palavras-chave: óleo de andiroba, Carapa guianensis, ácidos graxos.

\section{INTRODUCTION}

Species of the family Meliaceae (Sapindales) shows great commercial value such as Cedrela fissilis, Cedrela odorata, Swietenia macrophylla, and some of them can be used in landscaping (Guarea Guidonia and Melia azadarach), or in environmental recovery (Trichilia claussenii), and also in folk medicine (Carapa guianensis, Carapa procera, and Azadirachta indica). In Brazil, the species of this family are found especially in Amazon and Atlantic Forests, occupying lowland and upland areas [1]. 
In the Brazilian Amazon, the species Carapa guianensis Aubl. stands out and is popularly known as andirobeira, a large tree, reaching up to $55 \mathrm{~m}$ in height, and the part of the trunk that originates from the roots towards the branches, is cylindrical and straight. The bark is thick and bitter, reddish or greyish in color, and the leaves are alternate, composed, with full margins, and bright dark green. The flowers are grouped at the end of the branches (inflorescence), white to cream in color, and lightly scented [2].

The herbal C. guianensis (andiroba), is considered one of the most valuable species in the Northern region of Brazil, whose wood is used in the construction of houses, furniture, and boats, while the seeds are useful for oil extraction [3]. Because of its broad biological activity $C$. guianensis oil is widely consumed in folk medicine, with medicinal properties such as: analgesic [4], anti-bacterial [5-7], anti-inflammatory [8], anti-fungal [9], anti-allergic [10], anti-malarial [11], antioxidant [12], and healing properties. Additionally, it is also effective in the treatment of bruises, herpes ulcers, rheumatism, and ear infections, and as repellent against insect bites [1315].

The oil extracted from $C$. guianensis seeds has yellow color, bitter taste, is rich in fatty acids and, at temperatures below $25^{\circ} \mathrm{C}$, it solidifies. However, the andiroba oil normally contains about $5 \%$ of non-saponifiable material, in which the limonoids andirolide A-Y, carapanolides, and carapanosins stand out [5-7]. Other compounds include triterpenes, flavonoids, coumarins, benzoic acid derivatives (3,4- and 2,6-dihydroxymethylbenzoate), and long chain fatty acids (tetratriacontanoic and triacontanoic acids) [16].

Manual extraction of andiroba oil varies according to the culture and knowledge of each community. However, the steps of collecting and selecting seeds, dough preparation (andiroba bread), and oil extracting are performed by all members of the community [3]. The various benefits to human health attributed to andiroba oil reinforce the importance of develop studies concerning to its chemical composition. In this sense, the present study aimed to analyze, by gas chromatography coupled to mass spectrometry (GC/MS), the chemical composition of andiroba oil, manually extracted in the Mamangal community, located in Igarapé-Miri, Pará.

\section{MATERIALS AND METHODS}

This research is part of the project "Ethnocognition of medicinal plants grown in backyards in the community of Mamangal, Meruú River, Igarapé-Miri, Pará" and is registered in the National System for the Management of Genetic Heritage and Associated Traditional Knowledge (SisGen), under the number A2B82CE. The research was submitted and approved by Platform Brazil system and Ethics Committee of the Institute of Health Sciences (UFPA), under the registration number CAAE- 89148418.7.0000.0018.

\subsection{Collection and botanical identification}

Plant collection and visits to Mamangal community were carried out through a guided tour, from August to October 2018. Herborization process followed techniques described by Ming (1996) [17], and the species identification was based on specialized literature and consultations to platforms Flora do Brasil 2020 and Missouri Botanical Garden. A voucher specimen (R.L. Sousa et al. 46, HIFPA1906) has been deposited in the biological collection of the Federal Institute of Pará Herbarium, in Abaetetuba, Pará.

\subsection{Oil extraction}

The andiroba fruit is a brown hedgehog and, when it is ripe, it falls from the trees to the ground. The impact of this fall causes the fruit to open, releasing 4 to 16 seeds, which are rich in oil (Figure $1)$. 


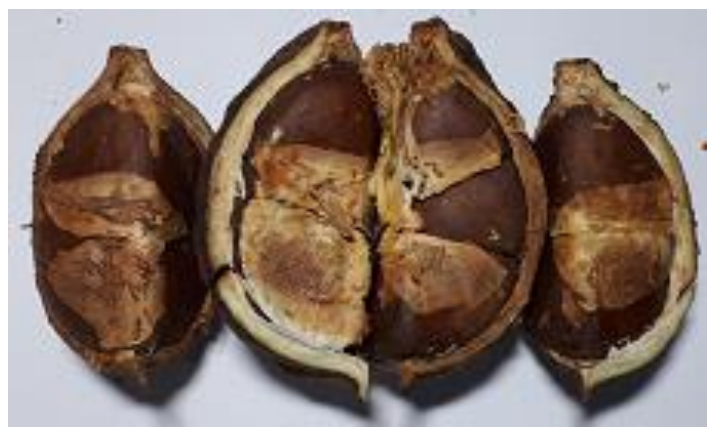

Figure 1. Andiroba fruit with seeds after falling from the tree.

The oil from andiroba seeds was extracted by a resident of Mamangal community (01 ${ }^{\circ} 53^{\prime} 274$ ' 'S; 49 $01^{\prime}$ '701' 'W), located on the banks of Mamangal Grande River. The extraction method used was the traditional one, which began with the manual collection of seeds in places, such as the forest, under trees, floating on Mamangal Grande river, or in floodplain areas. The next phase consisted of seed selection, based on color, smell, and germination process. Then, the selected nuts were subjected to cooking over a wood fire for about an hour and a half, and the correct cooking point was verified by shell breaking and nut flexibility. In resting phase, the seeds were placed in a pan and kept for 30 days. After that period, the pulp was removed, molded into ball shapes (andiroba bread) and placed on a board. This extraction phase lasted 25 days and the andiroba bread was smashed two to five times/day [18].

\subsection{Oil analysis}

Initially, the andiroba oil was subjected to lipid esterification, according to the methodology by Khan and Scheinmann (1997) [19]. Subsequently, fatty acid methyl esters were analyzed by Gas Chromatography/Mass Spectrometry (GC/MS), as described by Silva et al. (2009) [20] and Silva (2018) [21], which was adapted in a Shimadzu QP Plus-2010 system, under the following conditions: capillary silica column Rtx-5MS (30 m x $0.25 \mathrm{~mm}$; $0.25 \mu \mathrm{m}$ film thickness); oven temperature programming starting in $100^{\circ} \mathrm{C}(5 \mathrm{~min})$ and then with a gradient of $4^{\circ} \mathrm{C} / \mathrm{min}$ up to

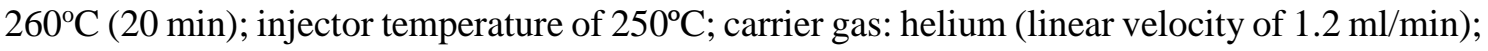
split-type injection of $1.0 \mu \mathrm{l}$ of the sample. Ionization was achieved by electronic impact technique at $70 \mathrm{eV}$; temperatures of ion source and transfer line in $220^{\circ} \mathrm{C}$ and $250^{\circ} \mathrm{C}$, respectively. The quantification of the sample was performed by gas chromatography using a flame ionization detector (FID) (Shimadzu QP 2010 system), under the same conditions as the GC/MS, except that nitrogen was used as carrier gas. The identification of sample components was based on the linear retention index (RI) calculated in relation to the retention times of a homologous series of $\mathrm{n}$-alkanes, their retention times, and on fragmentation pattern observed in mass spectra, by comparing these values with authentic fatty acids samples existing in Adams (2007) [22] and Nist (NIST - National Institute of Standards and Technology, 2011) databases.

\section{RESULTS AND DISCUSSION}

In total, nine chemical constituents have been quantified and identified by GC/MS analysis representing $99.63 \%$ of andiroba oil constituents, from which $42.06 \%$ of saturated fatty acids and $57.57 \%$ of unsaturated fatty acids (Table 1 and Figure 2). 
Table 1. Profile of fatty acids methyl esters from andiroba seed oil.

\begin{tabular}{llr}
\hline RI & Fatty acid methyl ester & $\%$ \\
\hline 1725 & Tetradecanoic acid, methyl ester & 0.03 \\
1905 & Palmitelaidic acid, methyl ester & 1.09 \\
1934 & Palmitic acid, methyl ester & 27.3 \\
2096 & Leinoleic acid, methyl ester & 9.29 \\
2109 & Oleic acid, methyl ester & 47.19 \\
2133 & stearic acid, methyl ester & 12.52 \\
2329 & Arachidic acid, methyl ester & 1.87 \\
2527 & Docosanoic acid, methyl ester & 0.25 \\
2730 & Tetracosanoic acid, methyl ester & 0.09 \\
& saturated fatty acids & 42.06 \\
& unsaturated fatty acids & 57.57 \\
\hline
\end{tabular}

RI: Calculated retention index (Rtx-5MS column)

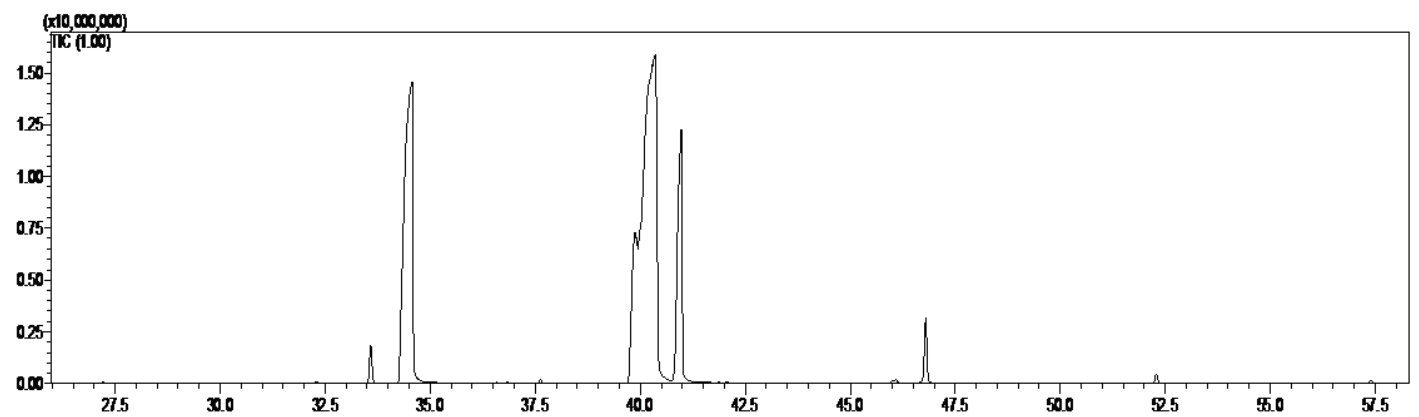

Figure 2. Total ion chromatogram of fatty acid methyl esters from andiroba seed oil.

The main components found were oleic (47.19\%), palmitic (27.3\%), stearic (12.52\%), and linoleic acids (9.29\%) (Figure 3). The results obtained in this study are in accordance previously reports performed with andiroba oil $[12,21,23]$.
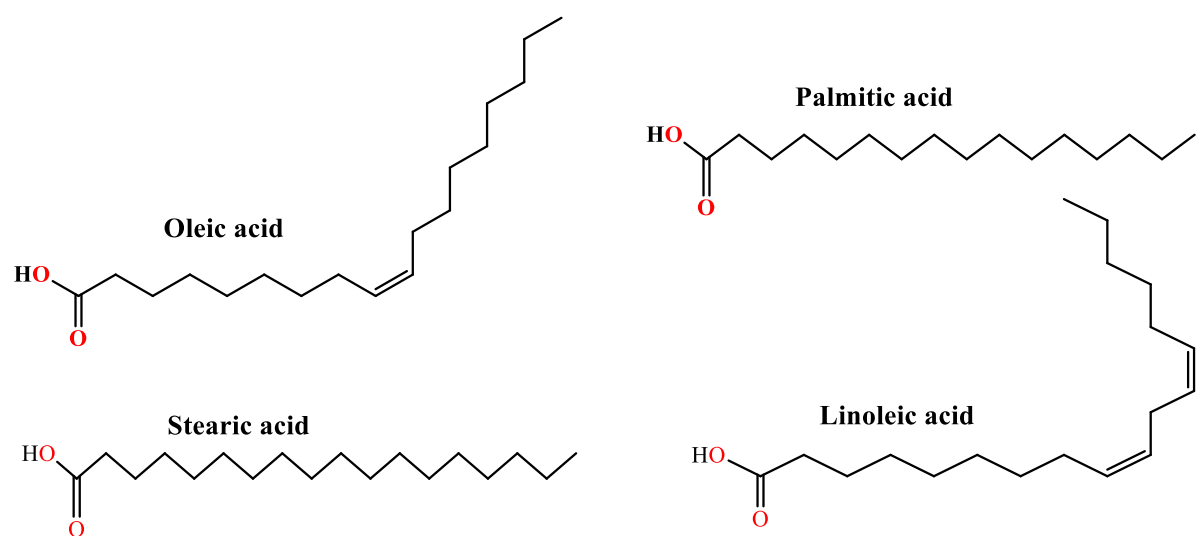

Figure 3. 2D chemical structures of the main compounds identified in andiroba seed oil (C. guianensis).

The oil extracted from C. guianensis seeds is widely used in folk medicine in the Northern region of Brazil. According to De Sousa et al. 2019 [18, 24], in studies carried out in two rural communities in Pará state, andiroba oil mixed with honey, "cabacinha" seed oil or castor oil, was indicated for treatment of cough, sinusitis, muscle strains, edema, and ecchymosis. While fresh 
and unmixed oil was widely used for healing skin wounds in humans and pets, sore throats or internal inflammatory processes $[18,24]$.

Under laboratory conditions, the topical use of andiroba oil was effective in tissue formation, epithelialization, angiogenesis, and collagen deposition in skin lesions, when compared to the control group [25]. Likewise, the ethanolic extract of $C$. guianensis leaves contributed to the increase in wound contraction rate, resistance to skin breakage, and improvement in hydroxyproline content of granulation tissue [14]. These benefits attributed to andiroba oil may be due to the fatty acids present in its chemical composition, as they contribute to the synthesis of biologically active compounds.

Oleic acid was the fatty acid found in greater proportion in andiroba oil, confirming the results found in ethnobotanical and pharmacological studies that point out several benefits of this oil to human health [26-28]. Other works have shown that this fatty acid prevented the risk of developing rheumatoid arthritis by increasing levels of leukotriene A3, a potent LTB4 leukotriene inhibitor [29]. In breast cancer cells, oleic acid reduced the expression of Her-2/neu oncogene and acted synergistically with the anti-cancer trastuzumab [30]. Oleic acid may be a therapeutic option for lipid dysregulation, as it signaled SIRT1-PGC1 complex to increase the oxidation rates of fatty acids [31]. In addition, it reduced the inflammatory effects of long-chain saturated fatty acids on human aortic endothelial cells, reducing cellular incorporation of stearic acid and activation of NF- $\kappa \mathrm{B}[32]$.

Palmitic and stearic acids represented $39.82 \%$ of $C$. guianensis oil composition. According to Marsiñach and Cuenca (2019) [33], these saturated fatty acids are not known for being beneficial to health when taken orally. However, they can be interesting if administered topically due to their molecular structure. Saturated fatty acids tend to be stronger than unsaturated fatty acids, and consequently, more occlusive. This property can be beneficial for skin disorders, such as dermal dehydration. Saturated fatty acids form a protective barrier on the skin, enabling a valuable clinical application, as it prevents water loss and facilitates the absorption of other bioactive compounds present in the oil.

In the composition of andiroba oil, linoleic acid represented $9.29 \%$ of the fatty acids identified and quantified by GC/MS, which constitutes about $40 \%$ of the fatty acids in human skin, mainly used in treatment of skin wounds [34, 35]. In 2014, Cela et al. [36] attested the efficacy and safety of the emulsion based on andiroba oil to relieve pain and erythema caused by depilation with intense pulsed light. As well, the same formulation demonstrated analgesic and anti-inflammatory potentials after photoepilation [36]. The evaluation of $C$. guianensis ethanolic extract in topical treatment of excision wounds did not demonstrate antibacterial activity, but great healing potential [14]. The topical application of andiroba oil also had significant effect on wound healing under certain experimental conditions [25].

The description of the chemical profile of $C$. guianensis oil empirically contributes to affirm its medicinal use. These results are in accordance with the study by Penido et al. (2006) [8], who described relevant data regarding the anti-inflammatory effect of andiroba oil, inhibiting Zymosan-induced arthritis in mice. It also reduced the degree of oral mucositis induced by 5-fluorouracil in mice [37].

The andiroba oil commercialized and consumed in the Baixo Tocantins region (Pará, Brazil) is extracted, in general, manually, as it is a cheap extraction method and does not require the use of electricity. It is suggested that the extraction technique does not alter the chemical composition of the product, according to a study developed by Araujo-Lima et al. (2018) [23], since they tested three methods of extracting $C$. guianensis seed oil, and found that these different processes did not alter its physicochemical aspects.

The extraction of andiroba seed oil in the Mamangal community occurs in a sustainable way, and the community members respect the productive cycle of $C$. guianensis species. The seeds were collected in the forest under the trees or floating in the floodplain areas because during high tides period, there are places where the seeds are deposited, and in others, they are dragged by the current of rivers and watercourses.

The andiroba oil production chain involves seed collectors, extractors, middlemen, and local and external consumers. The local consumer corresponds to family, neighbors, and friends. In relation to external consumers, commercialization was mentioned, such as in Igarapé-Miri, 
Barcarena, and Abaetetuba cities, in Ver-o-Peso fair in Belém (Pará, Brazil), and in pharmacies. The middlemen were represented by people known in the community, who buy all stored production.

The commercialization of andiroba oil in the Mamangal community is an activity considered to be profitable, as extractors reported selling the entire production quickly, as there is a great demand. The price of a liter of oil in the second half of 2019 ranged from 40.00 BRL to 65.00 BRL. According to the extractor who donated the oil for this research, the largest production of seeds coincides with the rainiest period, but in the years when the months of July to November are very rainy, the andiroba trees bear fruit all year round. This climatic factor, according to the participant, is important, as it guarantees the oil sale without interruption, and income complementation.

Andiroba plant is included in the National List of Medicinal Plants of Interest to the Unified Health System, which reinforces the importance of qualitative and quantitative analyses. Thus, based on the GC/MS technique, it was possible to infer that the consumption or topical use of andiroba oil does not cause damage to human health, since its major constituents are present in other oils that are part of the general population diet, such as olive and sunflower oils. Furthermore, the results of other studies carried out under certain experimental conditions with rats did not show any toxic [38] or genotoxic effects [12], and did not interfere with their fertility [39].

\section{CONCLUSION}

The manual extraction of andiroba seed oil in the Mamangal community is sustainable and economically viable. Carapa guianensis oil can be considered useful for pharmaceutical and cosmetic industries, due to the high content of saturated and unsaturated fatty acids. Unsaturated fatty acids represented $57.5 \%$ of the analyzed oil constituents, among which the essential ones stand out, as they have great applicability in the formulation of healing drugs.

\section{ACKNOWLEDGEMENTS}

To the Federal University of Pará, Adolpho Ducke Laboratory and the Herbarium of the Federal Institute of Pará-Campus Abaetetuba. To the Employees who agreed to participate in this research. The author Mozaniel Santana de Oliveira, thanks PCI-MCTIC/MPEG, as well as CNPq for the scholarship process number 302203/2020-6.

\section{REFERENCES}

1. Sakuragui CM, Calazans LSB, Stefano MV, Valente ASM, Maurenza D, Kutschenko DC, et al. Meliacea. In: Martinelli G, Moraes MA, organizadores. Livro vermelho da flora do Brasil. Tradução de Anderson F, Hieatt C. 1. ed. Rio de Janeiro: Andrea Jakobsson, Instituto de Pesquisas Jardim Botânico do Rio de Janeiro; 2013.

2. Ferraz IDK, Camargo JLC, Sampaio PDTB. Sementes e plântulas de andiroba (Carapa guianensis Aubl. e Carapa procera D.C.): Aspectos botânicos, ecológicos e tecnológicos. Acta Amaz. 2002;32(4):647-661. doi: 1809-43922002324661

3. Mendonça AP, Ferraz IDK. Óleo de andiroba: processo tradicional de extração, uso e aspectos sociais no Estado do Amazonas, Brasil. Acta Amaz. 2007;37(3):353-64. doi: 10.1590/S004459672007000300006

4. Penido C, Costa KA, Pennaforte RJ, Costa MF, Pereira JF, Siani AC, et al. Anti-allergic effects of natural tetranortriterpenoides isolated from Carapa guianensis Aublet on allergen-induced vascular permeability and hyperalgesia. Inflamm Res. 2005 Jul;54(7):295-303. doi: 10.1007 / s00011-005-13576

5. Higuchi K, Miyake T, Ohmori S, Tani Y, Minoura K, Kikuchi T, et al. Carapanosins A-C from Seeds of Andiroba (Carapa guianensis, Meliaceae) and their effects on LPS-Activated NO Production. Molecules. 2017; 22(3):502. doi: 10.3390/molecules22030502 
6. Matsui Y, Kikuchi T, Inoue T, Muraoka O, Yamada T, Tanaka R. Carapanolides J-L from the Seeds of Carapa guianensis (Andiroba) and their effects on LPS-Activated NO Production. Molecules. 2014;19(11):17130-40. doi: 10.3390/molecules191117130

7. Miyake T, Ishimoto S, Ishimatsu N, Higuchi K, Minoura K, Kikushi T, et al. Carapanolides T-X from Carapa guianensis (Andiroba) Seeds Molecules. 2015;20(11):20955-66. doi: 10.3390/molecules201119737

8. Penido C, Conte FP, Chagas MS, Rodrigues CA, Pereira JF, Henriques MG. Antiinflammatory effects of natural tetranortriterpenoids isolated from Carapa guianensis Aublet on zymosan-induced arthritis in mice. Inflamm Res. 2006;55(11):457-64. doi: 10.1007/s00011-006-5161-8

9. Ferreira MC, Vieira MLA, Zani CL, Alves TMA, Junior PAS, Murta SMF, et al. Molecular phylogeny, diversity, symbiosis and discover of bioactive compounds of endophytic fungi associated with the medicinal Amazonian plant Carapa guianensis Aublet (Meliaceae). Biochem Syst Ecol. 2015;59:3644. doi: 10.1016/j.bse.2014.12.017

10. Ferraris FK, Rodrigues R, SILVA RRV, Figueiredo R, Penido C, Henriques MGMO. Modulation of T lymphocyte and eosinophil functions in vitro by natural tetranortriterpenoids isolated from Carapa guianensis Aublet. Int Immunopharmocol. 2011Jan;11(1):1-11. doi: 10.1016/j.intmp.2010.09.010

11. Pereira TB, Silva LFR, Amorim RCN, Melo MRS, Souza RCZ, Eberlin MN, et al. In vitro and in vivo anti-malarial activity of limonoids from the residual seed biomass from Carapa guianensis (andiroba) oil production. Malarial Journal. 2014;13:317.

12. Milhomem-Paixão SSR, Fascineli ML, Roll MM, Longo JPF, Azevedo RB, Pieczarka JC, et al. The lipidome, genotoxicity, hematotoxicity and antioxidant properties of andiroba oil from the Brazilian Amazon. Genet Mol Biol. 2016;39(2): 248-56. doi: 10.1590/1678-4685-GMB-2015-0098

13. Miranda Júnior RN, Dolabela MF, Silva MN, Póvoa MM, Maia JG. Antiplasmodial activity of the andiroba (Carapa guianensis Aubl., Meaceae) oil and its limonoid-rich fraction. J Ethnopharmacol. 2012 Aug;142(3):679-83. doi: 10.1016/j.jep.2012.05.037

14. Nayak BS, Kanhai J, Milne DM, Pereira LP, Swanston WH. Experimental evaluation of ethanolic extract of Carapa guianensis leaf for its wound healing activity using three wound models. Evid Based Complement Altern Med.2010;2011:1-6. doi: 10.1093/ecam/nep160

15. Prophiro JS, Silva MA, Kanis LA, Rocha LC, Duque-Luna JE, Silva OS. First report on susceptibility of wild Aedes aegypti (Diptera: Culicidae) using Carapa guianensis (Meliaceae) and Copaifera sp. (leguminosa). Parasitol Res. 2012 Feb;110 (2):699-705. doi: 10.1007/s00436-011-2545-7

16. Qi SH, Wu DG, Zhang S, Luo XD. Constituents of Carapa guianensis Aubl. (Meliaceae). Pharmazie. 2004;59(6):488-90.

17. Ming LC. Coleta de plantas medicinais. In: Di Stasi LC, organizador. Plantas medicinais: Arte e ciência - Um guia de estudo interdisciplinar. São Paulo: Editora da Universidade Estadual Paulista; 1996.

18. De Sousa RL, Almeida BB, Silva RP, Albuquerque LCS, Cordeiro YEM. Óleo de andiroba: extração, comercialização e usos tradicionais na comunidade Mamangal, Igarapé-Miri, Pará. Biodiversidade. 2019;18(1):68-81.

19. Khan GR, Scheinmann F. Some recent advances in physical methods for analysis and characterization of polyunsaturated fatty acids. Prog Chem Fats Other Lipids. 1997;15(4):343-67. doi: 10.1016/00796832(77)90012-x

20. Silva VP, Oliveira RR, Figueiredo MR. Isoloation of limonoids from seeds of Carapa guianensis Aublet (Meliaceae) by high-speed countercurrent chromatography. Phytochem Anal. 2009;20(1):77-81. doi: $10.1002 /$ pca. 1100

21. Silva LR. Propriedades físico-químicas e perfil dos ácidos graxos do óleo da andiroba. Nativa. 2018 Mar/Abr;6(2):147-52. doi: 10.31413/nativa.v6i2.4729

22. Adams RP. Identification of essential oil components by Gas Chromatography/Mass Spectroscopy. 4th ed. Carol Stream (IL): Allured Pub Corp; 2007.

23. Araujo-Lima CF, Fernandes AS, Gomes EM, Oliveira LL, Macedo AF, Antoniassi R, et al. Antioxidant activity and genotoxic assessment of crabwood (Andiroba, Carapa guianensis Aublet) seed oils. Oxid Med Cell Long. 2018;2018:11. doi: 10.1155/2018/3246719

24. De Sousa RL, Miranda AUS, Cordeiro YEM, Pereira MG. Extração e comercialização do óleo de andiroba (Carapa guianensis Aublet.) na comunidade da Ilha das Onças, no município de Barcarena, Pará, Brasil. INTERAÇÕES. 2019;20(3):879-89. doi: 10.20435/inter.v0i0.1826

25. Souza BAA, Braga LA, Oliveira Lopes LR, Ribeiro Júnior RFG, Nascimento LNS, Cavalcante LCC, et al. Effects of andiroba oil (Carapa guianensis) on wound healing in alloxan-diabetic rats. Int Ach Med. 2017;10(263):1-6. doi: 10.3823/2533

26. Burlando B, Cornara L. Revisiting amazonian plants for skin care and disease. Cosmetics. 2017;4(25):112. doi: $10.3390 /$ cosmetics 4030025 
27. Leal JB, Silva MM, Costa JM, Albuquerque LCS, Pereira MGS, De Sousa RL. Etnobotânica de plantas medicinais com potencial anti-inflamatório utilizadas pelos moradores de duas comunidades no município Abaetetuba, Pará. Biodiversidade. 2019;18(3):110-25.

28. Santos EQ, Costa JFS, Pereira MGS, Costa JM, Sousa RL. Etnobotânica da flora medicinal de quintais na comunidade Mamangal, Igarapé-Miri, PA. Sci Plena. 2019;15(5):1-11. doi: 10.14808/sci.plena.2019.051202

29. Berbet AA, Kondo CRM, Almendra CL, Matsuo T. Supplementation of fish oil and olive oil in patients with rheumatoid arthritis. 2005; Nutrition. 21(2):131-6. doi: 10.1016/j.nut.2004.03.023

30. Menendez JA, Vellon L, Colomer R, Lupu R. Oleic acid, the main monounsaturated fatty acid of olive oil, suppresses Her-2/neu (erb B-2) expression and synergistically enhances the growth inhibitory effects of trastuzumab (Herceptine) in breast cancer cells with Her-2/neu oncogene amplification. Ann Oncol. 2005;16:359-71. doi: 10.1093/annonc/mdi090

31. Lim J-H, Gerhart-Hines Z, Dominy JE, Lee Y, Kim S, Tabata M, et al. Oleic acid stimulates complete oxidation of fatty acids through protein Kinase A-dependent activation of SIRT1-PGC1 $\alpha$ complex. J Biol Chem. 2013 Jan;288(10):7117-26. doi: 10.1074/jbc.M112.415729

32. Harvey KA, Walker CL, Xu Z, Whitley P, Pavlina TM, Hise M, et al. Oleic acid inhibits stearic acidinduced inhibition of cell growth and pro-inflammatory responses in human aortic endothelial cells. $\mathrm{J}$ Lipid Res. 2010 Dec;51(12):3470-80. doi: 10.1194/jlr.M010371

33. Marsiñach MS, Cuenca AP. The impact of sea buckthorn oil fatty acids on human health. Lipids Health Dis. 2019;18:145. doi: 10.1186/s12944-019-1065-9

34. Declair V. The usefulness of topical application of essential fatty acids (EFA) to prevent pressure ulcers. Ostomy Wound Manage. 1997 Jun;43(5):48-52.

35. Lania BG, Morari J, Almeida AR, Silva MN, Vieira-Damiani G, Lins KA, et al. Topical essential fatty acid oil on wounds: Local and systemic effects. PLoS ONE. 2019;14(1):e0210059. doi: 10.1371/journal.pone.0210059

36. Cela EVSS, Rocha MB, Chia CY, Alves CF. Treatment of first-degree burns with andiroba oil emulsion: a prospective, comparative, double-blind study. Surg Cosmet Dermatol. 2014;6 (1):44-9.

37. Wanzeler AMV, Júnior SMA, Gomes JT, Gouveia EHH, Henriques HYB, Chaves RH, et al. Therapeutic effect of andiroba oil (Carapa guianensis Aubl.) against oral mucositis: an experimental study in golden Syrian hamsters. Clin Oral Investig. 2018;22(5):2069-79. doi: 10.1007/s00784-017$2300-2$

38. Costa-Silva JH, Lima CR, Silva EJ, Araújo AV, Fraga MCCA, Ribeiro A. Acute and subacute toxicity of the Carapa guianensis Aublet (Meliaceae) seed oil. J Ethnopharmacol. 2008;116(3):495-500. doi: 10.1016/j.jep.2007.12.016

39. Costa-Silva JH, Lyra MM, Lima CR, Arruda VM, Araújo AV, Ribeiro A. A toxicological evaluation of the effect of Carapa guianensis Aublet on pregnancy in Wistar rats. J Ethnopharmacol. 2007;112(1):122-6. doi: 10.1016/j.jep.2007.02.004 